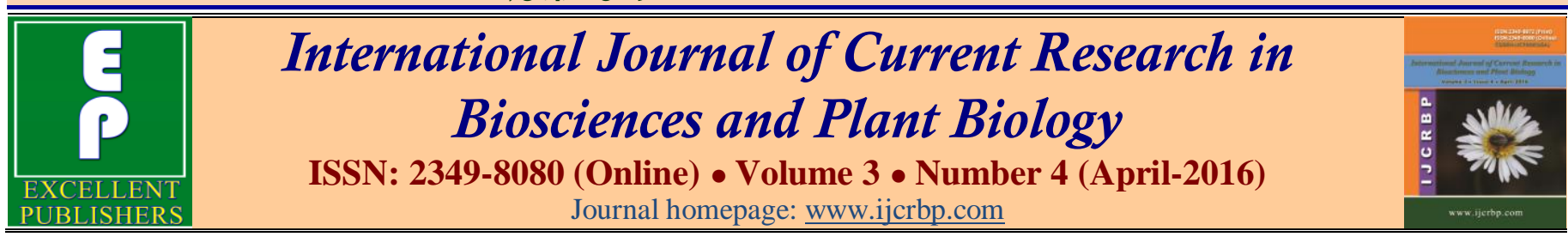

\title{
Effects of Different Concentrations of Palm Oil Effluent (POME) on the Germination of Seed of Glycine max L. and Abelmoschus esculentus L.
}

\author{
N. H. Ifediora* and L. N. Awazie \\ Department of Plant Science and Biotechnology, Michael Okpara University of Agriculture, Umudike, Abia State, Nigeria \\ *Corresponding author.
}

\begin{abstract}
A bstract
The study was carried out to evaluate the effect of palm oil mill effluent (POME) on seed germination percentages of Glycine max (soya bean) and Abelmoschus esculentus (okro). The seeds were raised in Petri dishes, irrigated with different concentrations of POME $(25 \%, 50 \%, 75 \%$ and $100 \%)$ and Petri dishes containing distilled water served as the control. Each treatment was replicated three times including the control with ten seeds planted in each Petri dish. The seeds were allowed for five days to germinate. At low concentration 25\% of POME, the seeds of Glycine max, and Abelmoscus esculentus showed highest tolerance. Glycine max showed the highest tolerance to the pollutant (POME) with maximum germination percentage of $93.33 \%$ at the treatment level of $25 \%$ and $80.00 \%$ at control while Abelmoscus esculentus had $40.00 \%$ at control and $25 \%$. The germination percentage of both seeds at $50 \%, 75 \%$, and $100 \%$ concentration of POME were low when compared to the seeds grown in 25\% concentration of POME and control. This experiment showed that low concentrations of POME had low inhibitory effects on the germination percentages of Glycine max and Abelmoscus esculentus while high concentrations of POME showed increased inhibitory effects on the germination percentages of both seeds.
\end{abstract}

\section{Introduction}

Agro industrial effluents' management has been a major issue of environmental concern globally (Nwoko et al., 2010). When palm oil is extracted and processed, it also produces effluents with high organic matter, suspended matter, oil and grease (Sridhar and AdeOluwa, 2009; Rupani et al., 2010; Ma, 1999; Ma, 2000). Gaseous emissions are often unreported. These processing wastes if not adequately managed causes adverse environmental impacts including land and aquatic ecosystem contamination, loss of land and resources, negative impacts on soil micro flora and fauna and loss of biodiversity (Sridhar and AdeOluwa, 2009). Since these compounds are harmful to the environment, it becomes necessary that effluent water should be treated or purified before discharged into the environment. Thus, the major objective of industrial effluents treatment is to reduce the amount of these potentially toxic compounds to acceptable threshold limit value according to the standards of the Federal Ministry of Environment.

The biochemical oxygen demand (BOD) of these waste are usually high $(>10,000 \mathrm{mg} / \mathrm{l})$ (Nwoko et al., 2010; Yahaya and Lau, 2013). POME consists of water soluble components of palm fruits as well as suspended materials like oil residues, short palm fiber, cell walls, organelles, a variety of carbohydrates ranging from cellulose to simple sugars, a range of nitrogenous compounds from proteins to amino acids, free organic acids and assembly of minor organic and mineral constituents (Ugoji, 1997). Nutrients contents in POME are nitrogen, phosphorus, 
potassium, magnesium and calcium, which are the vital nutrient elements for plant growth (Habib et al., 1997; Muhrizal et al., 2006). Due to the non-toxic nature and fertilizing properties, POME can be used as fertilizer or animal feed substitute, in terms of providing sufficient mineral requirements (Yahaya and Lau, 2013).

POME is generated at various points during processing in an oil mill. These include; clarification sludge, sterilization condensate, fruit washing water, hydro cyclone drain-off, various boiler blows down, tank and decanters drains (Yahaya and Lau, 2013). Raw POME is a colloidal suspension containing 95\%-96\% water, 0.6$0.7 \%$ oil and $4-5 \%$ total solids including $2-4 \%$ suspended solids that are mainly consisted of debris from palm fruit mesocarp generated from three main sources, namely sterilizer condensate (36\%), separator sludge or clarification (60\%) and hydro cyclone(4\%) wastewater (Borja and Banks, 1994; Ma, 2000).

Pollution caused by different industries is a serious concern worldwide. During the last century, a great deal of research and development as well as application has been devoted to pollution control advance technologies for treatment and management of both solid and liquid waste generated from palm oil mills. The major reason for such huge efforts is that waste generation from palm oil mills have been declared as one of the major source of environmental pollution (Yahaya and Lau, 2013). For every metric ton of palm oil produced, 2.5 metric tonnes of effluent (POME) are generated from processing in palm oil in mills. Direct release of this effluent causes freshwater pollution, which can affect downstream biodiversity and people (Ma, 2000).

Water resource is often affected by industrial pollution as they release their effluent with or without treatment in nearby water bodies. These effluent streams are normally disposed of in drainage channels or stored in evaporation ponds or worse still discharged into arable lands to possibly avert the cost of treatment. This practice is predominant in developing countries where effluent discharge standards are not strictly adhered to (Nwoko et al., 2010).

The rapid rise of palm oil production has made it the most important oil in the world in the last few decade (Yahaya and Lau, 2013). Ogboi et al (2010) observed in South Central Nigeria that all the Palm Oil Processing Waste (POME) are being disposed of indiscriminately on the ground. It therefore becomes necessary to look at the impact of this waste on the soil and crop performance.
There are a number of studies on the impact of industrial or domestic effluents on soil properties and crop response (Sharma, et al., 2007; Singh and Agrawal, 2010). There is paucity of study on the effects of POME on the germination of the seeds of Glycine max and Abelmoscus esculentus and thus dearth of information. This current study is aim at determining the effect of Palm Oil Mill Effluent on seed germination percentage.

\section{Materials and methods}

The study was carried out in the laboratory of Department of Plant Science and Biotechnology, Michael Okpara University of Agriculture, Umudike, Abia State, Nigeria. Umudike is located at longitude $07^{\circ} 32^{\prime \prime}$ to $07^{\circ} 34^{\prime \prime} \mathrm{E}$ and latitude $05^{\circ} 28$ to $05^{\circ} 29^{\prime \prime} \mathrm{N}$; elevation of $122 \mathrm{~m}$ above sea level. The seeds of Glycine max and Abelmoscus esculentus were collected from National Root Crop Research Institute (NRCRI), Umudike, Abia State. The palm oil mill effluent (POME) was collected in pre-cleaned 10 litre plastic container from the point of discharge in a local palm oil mill at Ubakala, Umuahia South L.G.A, Abia State. The effluent temperature was measured and stored at $4^{\circ} \mathrm{C}$ to avoid changes in their physiochemical characteristics.

The seeds of G. max and A. esculentus were subjected to viability test using floating technique which involves putting the seeds into a beaker filled with distilled water. The beaker was allowed to stand for a minute. The seeds floating on top of the water were discarded while those at the bottom were used for the study. The sterile Petri dishes were stuffed with cotton wool prior to seed planting. The seeds were sown in Petri dishes with cotton wool moistened with the different concentrations of POME $(25 \mathrm{ml}, 50 \mathrm{ml} 75 \mathrm{ml}$ and $100 \mathrm{ml})$ in three replicates (10 seeds in each Petri dish) (Nwokeocha and Ezumah, 2014). Distilled water was used for three Petri-dishes that served as the control. The seeds were allowed for five days to germinate with once a day wetting of the dishes to avoid drying up (Nwokeocha and Ezumah, 2014). The numbers of germinated seeds in each treatment were counted on the fifth day and germination percent was calculated using the following formula (Nwokocha and Ezumah, 2014).

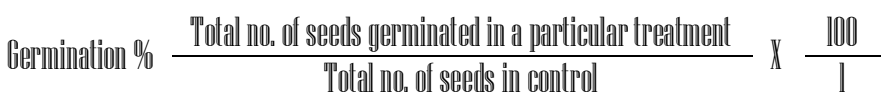

The difference between the number planted and the number that germinated under different treatments was tested and compared using paired $\mathrm{t}$-test (Ogbeibu, 2005). 


\section{Results}

The physiochemical analysis of the POME, the number of seeds planted, number of germinations and percentage germination are presented in Tables 1,2 and 3. The result showed that the POME) was acidic in nature $(5.8-6.0)$ with a mean of 5.9 (Table 1). It also showed that as the concentration of POME increased from 0\% (control) to $100 \%$, the percentage germinations in G. max increased from $80.00 \%$ to $93.33 \%$ in control and $25 \%$, then decreased to $66.33 \%$ in $50 \%, 53.33 \%$ in $75 \%$ and $33.33 \%$ in $100 \%$. (Table 2). For A. esculentus, the germination percentage were the same $40 \%$ in control and $25 \%$, then decreased to $20 \%$ in $50 \%, 10 \%$ in $75 \%$ and $6.67 \%$ in $100 \%$. The maximum inhibition was recorded at $100 \%$ concentration in both seeds while the minimum was recorded at $25 \%$ concentration in G. max and control and $25 \%$ in A. esculentus. The effect of POME on both seeds followed the same trend. Paired ttest analysis showed that there was significant difference $(p<0.05)$ between the number of seeds planted and the number that germinated (since $t$ Stat $>$ t Critical two-tail) in both seeds. This difference is attributed to the inhibitory effect of the POME.

Table 1. Physicochemical analysis of palm oil mill effluent (POME).

\begin{tabular}{ll}
\hline Parameters & Mean \\
\hline $\mathrm{pH}$ & 5.90 \\
Electrical conductivity $(\mathrm{EC})$ & 6.59 \\
Total suspended solid (mg/L) & 1871.12 \\
Total dissolved solid (mg/L) & 446.12 \\
Chemical oxygen demand (mg/L) & 157.684 \\
Biochemical oxygen demand (mg/L) & 360.444 \\
Total Kjeldahl nitrogen (mg/L) & 17.29 \\
\hline
\end{tabular}

Table 2. Effects of POME on the germination percentage of Glycine max.

\begin{tabular}{llll}
\hline Treatments & Total number planted & Total number germinated & Percentage germination \\
\hline Control & 30 & 24 & 80.00 \\
$25 \%$ & 30 & 28 & 93.33 \\
$50 \%$ & 30 & 19 & 63.33 \\
$75 \%$ & 30 & 16 & 53.33 \\
$100 \%$ & 30 & 10 & 33.33 \\
\hline
\end{tabular}

Table 3. Effects of POME on the germination percentage of Abelmoscus esculentus.

\begin{tabular}{llll}
\hline Treatments & Total number planted & Total number germinated & Percentage germination \\
\hline Control $(0 \%)$ & 30 & 12 & 40.00 \\
$25 \%$ & 30 & 12 & 40.00 \\
$50 \%$ & 30 & 6 & 20.00 \\
$75 \%$ & 30 & 3 & 10.00 \\
$100 \%$ & 30 & 2 & 6.67 \\
\hline
\end{tabular}

\section{Discussion}

The Palm oil mill effluent (POME) was acidic in nature $(5.8-6.0)$ with a mean of 5.9 (Table 1$)$. These values are higher than those of Nwoko et al. (2010) and Rajeev et al (2013) that have mean values of 4.50 and 3.91 respectively. Typically, POME waste water is low in $\mathrm{pH}$ because of the organic acids produced in the fermentation process ranging about 4-5 (Parveen et al., 2010). Decrease in $\mathrm{pH}$ can be ascribed to acidic nature of POME having high available free ions (Singh et al., 2010). Soils with $\mathrm{pH}$ values below 5.5 are likely to contain exchangeable aluminum leached from clay minerals at high levels which could be toxic to plant. The
POME also had high levels of biochemical oxygen demand $(360.444 \mathrm{mg} / \mathrm{l})$, chemical oxygen demand $(157.684 \mathrm{mg} / \mathrm{L})$, total suspended solid $(1871.12 \mathrm{mg} / \mathrm{L})$ and electrical conductivity (6.97) (Table 1). Yahaya and Lau (2013) gave lower values of BOD $(25,000 \mathrm{mg} / \mathrm{L})$, COD $(5,000 \mathrm{mg} / \mathrm{L})$, and TSS $(18,000 \mathrm{mg} / \mathrm{L})$. The effluent was dark brown in color due to high suspended and dissolved solids as observed by Parveen et al. (2010) and Rajeev et al. (2013). The raw or partially treated POME has an extremely high content of degradable organic matter (Parveen et al., 2010). Palm oil mill effluent (POME) creates environmental problems due to discharge of effluents consisting of higher $\mathrm{pH}, \mathrm{EC}, \mathrm{BOD}, \mathrm{COD}$, TDS, total N, phosphate and sulphate content (Habib et al., 
1997; Muhrizal et al., 2006). High EC of POME alters the chelating properties of receiving water system, creating favourable conditions for metal availability to flora and fauna (Nanda et al., 1999). The $\mathrm{pH}$ of POME decreased at different ratios; however EC increased. The increase in EC and decrease in $\mathrm{pH}$ can be ascribed to acidic nature of POME having high available free ions (Singh et al., 2010). Total dissolved as well as suspended solids of different ratios of POME increased with increasing ratios.

The reduction in the amount of water absorption by seeds took place due to changes in the osmotic relationship of the seed and water, resulting into the retardation of seed germination due to enhanced salinity (Rajeev et al., 2013). The inhibitory effect shown by $100 \%$ concentration of POME may be due to high osmotic pressure at high dose, salts making imbibition more difficult and retarded germination (Nagda et al., 2006). The salt concentration outside of the seed is known to act as limiting factor and it might be responsible for delay in germination (Adraino et al., 1997). The other prospect of reduction in germination percentage at higher concentration of effluent may be due to existence of excess amount of ammonia in effluent, causing depletion of the tricarboxylic acid cycle which reduces the respiration rate and subsequently germination (Kirkby, 1967). According to Saxena et al. (1968), the low amount of oxygen in dissolved form due to the presence of higher concentration of solid in the effluent, reduces the energy supply through anaerobic respiration resulting in restriction of the growth and development of the seedling.

Comparatively, it was observed in this study that the germination percentages of both seeds; G. max, and A. esculentus varied in their response to different concentrations of POME. G. max showed the highest resistance by having the maximum germination of percentages of 80.0, 93.33, 63.33 and $53.33 \%$ in control, $25,50,75$ and $100 \%$ respectively. While $A$. esculentus had a minimum germination percentages of 40.00, 40.00, $20.00,10.00$ and $6.67 \%$ in control, 25, 50, 75 and $100 \%$ of POME concentrations. This shows that POME can have both positive and negative effects on crop performance. POME has a high nutrient content, and large oil palm plantations prefer to use it directly as fertilizer (Modise et al., 2006). The application of palm oil mill effluent was reported to increase the growth of maize (Ogboi et al., 2010) while The growth and germination inhibitions of different vegetables after POME application to the soil was observed by Radziah (2001).

\section{Conclusion}

From this study it will be concluded that at low concentrations and proper dilutions of POME, the effluent can be used in the cultivation of Glycine max. Since the higher concentration of the effluent is toxic to the plant growth, it is recommended that only after treatment and dilution, POME can be used as soil amendment for cultivation of Glycine max.

\section{Conflict of interest statement}

Authors declare that they have no conflict of interest.

\section{References}

Adraino, D. C., Chang, A. C., Pratt P. E., Sharpless, R., 1973. Effect of application of dairy manure on germination and emergence of some selected crops. J. Environ. Qual. 3, 396-399.

Borja, R., Banks, C. J., 1994. Anaerobic digestion of palm oil mill effluent using an up-flow anaerobic sludge blanket reactor. Biomass Bioenergy. 6, 381-389.

Habib, M.A.B., Yusoff, F.M.H., Phang, S.M., Mohamed, S., 1997. Nutritional values of chironomid larvae grown in palm oil mill effluent and algal culture. Aquacul. 158, 95105.

Kirkby, E.A., 1968. Influence of Ammonia and Nitrate nutrition on the cation balance and Nitrogen and Carbohydrate metabolism of white mustard plant groom in dilute nutrient solution. Soil Sci. 105-141.

Ma, A. N., 2000. Environmental Management for the Oil Palm Industry. Palm Oil Develop. 30, 1-10.

Ma, A.N., 1999. Treatment of palm oil mill effluent. In: Oil Palm and the Environment: A Malaysian Perspective (Eds.: Singh, G., Lim, K H., Leng, T., David, L. K.), Malaysian Oil Palm Growers' Council, Kuala Lampur. $277 \mathrm{p}$.

Modise, C. M., Bendick, J. A., Miller, C. J., Ronald, D. N., Vidic, R. D., 2006. Use of hydrophilic and hydrophobic microfiltration membranes to remove microorganisms and organic pollutants from primary effluents. Water Environ. Res. 78, 557-564.

Muhrizal, S., Shamshuddin, J., Fauziah, I., Husni, M.A.H., 2006. Changes in iron-poor acid sulfate soil upon submergence. Geoderma. 131, 110-122.

Nagda, G.K., Diwan, A.M., Ghole, V.S., 2006. Seed Germination bioassays to assess toxicity of molasses fermentation based bulk drug industry effluent. E-J. Environ. Agric. Food Chem. 5(6), 1598-1603.

Nanda, P., Sudharshan, P., Behera, M.K., 1999. Physiochemistry analysis of orient paper mill effluent. Environ. Ecol. 17, 975-977.

Nwokeocha, O.W., Ezumah, B.S., 2015. Effect of cashew leaves and stem-bark extracts on the germination of maize. Int. J. Plant Soil Sci. 4(5), 494-498. 
Nwoko, C.O., Ogunyemi, S., Nwokocha, E .E., Nnorom, I.C., 2010. Evaluation of phytotoxicity effect of palm oil mill effluent and cassava mill effluent on tomato (Lycopersicum esculentum) after pretreatment options. Int. J. Environ. Sci. Develop. 1(1), 67-72.

Ogbeibu, A.E., 2005. Biostatistics - A Practical Approach to Research and Data Handling. Mindex Publishing Company Limited, Benin City, Nigeria. pp.175-176.

Ogboi, E., Kperegbeyi, E.I., Odeh, H.O., Nmor., 2010. Maize performance; soil contamination; palm oil mill effluent. Afr. J. Gen. Agric. 6(1), 19-24.

Parveen, F.R., Rajeev, P.S., Hakimi, I.N., Norizan, E., 2010. Review of current palm oil mill effluent (POME) treatment methods: vermicomposting as a sustainable practice. World Appl. Sci. J. 11 (1), 70-81.

Radziah, O., 2001. Alleviation of phytotoxicity of raw POME by microorganism. Retrieved Sept. 2005, from www.agri.upm.edu.my/agrosearch/v3n2/irpa3.htm.

Rajeev, P.S., Asha, E., Mahamad, H.I., Pooja, S., 2013. Effect of different palm oil mill effluent (POME) concentrations on seed germination, seedling growth and physiological response of Kkidney bean (Phaseolus vulgaris). J. Environ. Sci. Sustain. 1(3), 97-102.

Rupani, P. F., Singh, R. P., Ibrahim, H., Norizan, M., 2010. Review of current palm oil mill effluent (POME) treatment methods: Vermicomposting as a sustainable practice. World Appl. Sci. J. 11(1), 70-81.
Saxena, R.M., Kewa, P.F., Yadav R.S., Bhatanager, A.K., 1986. Impact of tannery effluent on some pulse crop. Ind. J. Environ. Health. 28(4), 345-348.

Sharma, R.K., Agrawal, M., Marshall, F.M., 2007. Heavy metals contamination of soil and vegetables in suburban areas of Varanasi, India. Ecotoxicol. Environ. Saf. 66, 258-266.

Singh, A., Agrawal, M., 2010. Effects of municipal waste water irrigation on availability of heavy metals and morphophysiological characteristics of Beta vulgaris L., J. Environ. Biol. 31(5), 727-736.

Singh, R. P., Ibrahim, M.H., Norizan, E., Iliyana, M. S., 2010. Composting of waste from palm oil mill: A sustainable waste management practice. Rev. Environ. Sci. Biotech. 9, 331-344.

Sridhar, M.K.C., AdeOluwa, O.O., 2009. Palm oil industry residue. In: Biotechnology for Agro-industrial Residues Utilisation. (Eds.: Nigam, P.S., Pandey, A.), Springer, USA. pp.341-355.

Ugoji, E.O., 1997. Anaerobic digestion of palm oil mill effluent and its utilization as fertilizer for environmental protection. Renew. Energy. 10, 291-294.

Yahaya, S. M., Lau, S., 2013. Pollution control: how feasible is zero discharge concepts in Malaysia palm oil mills. Amer. J. Engineer. Res. 2(10), 239-252.

\section{How to cite this article:}

Ifediora, N. H., Awazie, L. N., 2016. Effects of different concentrations of palm oil effluent (POME) on the germination of seed of Glycine max L. and Abelmoschus esculentus L. Int. J. Curr. Res. Biosci. Plant Biol. 3(4), 15-19. doi: http://dx.doi.org/10.20546/ijcrbp.2016.304.003 